\title{
The War on Drugs of Philippines and Indonesia: A Literature Review
}

\author{
Dyah Mutiarin \\ Department of Government Affairs and Administration, Universitas Muhammadiyah \\ Yogyakarta- Indonesia \\ Tamantirto, Kasihan, Bantul, Yogyakarta 55130, Indonesia \\ Tel: +62 274387656 E-mail: dyahmutiarin@umy.ac.id
}

Queenie Pearl V. Tomaro (Corresponding author)

Department of Political Science, Mindanao State University- Iligan Institute of

Technology

Andres Bonifacio Avenue, Tibanga, Iligan City 9200, Philippines

Tel: + 639976286407 E-mail: queenietomaro@gmail.com

David N. Almarez

Department of Political Science, Mindanao State University- Iligan Institute of

Technology

Andres Bonifacio Avenue, Tibanga, Iligan City 9200, Philippines

E-mail: david.almarez@g.msuiit.edu.ph

Received: Dec. 16, 2018 Accepted: Jan. 21, 2019 Online published: Feb. 14, 2019

doi:10.5296/jpag.v9i1.14355 URL: https://doi.org/10.5296/jpag.v9i1.14355

\begin{abstract}
The paper explains the realities surrounding the Drug Wars of Indonesia and Philippines through a comparative lens. Analytically, the existing literature of both the Philippine case and Indonesian case about War on Drugs are scrutinized based on the context which depicts the severity of the drug problem; the strategies undertaken; the political figures of the Indonesian and Philippine Drug Wars, Joko Widodo and Rodrigo Duterte; and lastly, the criticisms surrounding the drug campaigns. Furthering the understanding of the prominent drug wars in
\end{abstract}


Southeast Asia becomes crucial with the surrounding international controversies of the drug campaigns alongside the wide domestic support both campaigns have garnered.

Keywords: war on drugs, Philippines, Indonesia

\section{Introduction}

In an international level, 247 million people have reportedly used drugs and 29 million suffer from drug use disorder but only 1 in 6 people with drug use disorder is in treatment (UNODC, 2016). In the year 2104, an estimated 207,400 drug-related deaths were recorded, corresponding to 43.5 deaths per million people aged 15-64 (UNODC, 2016). In addition, the highest estimated number of drug-related deaths by region in 2014 is the Asian region with an estimated drug-related death of 85,900. Drug use further multiplies into other drug-related issues of health such as HIV prevalence, Hepatitis C prevalence and drug overdose. Drug problem does not only pose a challenge on public health but also on peace and order. Despite the stable trends of amphetamine use globally, a report suggests that there is an increase in amphetamine use in east and Southeast Asia (UNODC, 2016). In fact, Asian countries emerge to be the largest amphetamine-type market and the most concentrated region of drug-injecting people in the world (Tanguay et al., 2015). Hence, it is not surprising that the Asian Governments have allocated huge budgets to address the issue of drugs. Asian countries have also favored 'prohibitionist model and punitive approaches grounded on the War on Drugs paradigm' (Tanguay et al., 2015, p. 10). In fact, the Philippine Government, and the Indonesian government have recently launched a strong campaign of War on Drugs- its own respective versions of War on Drugs. Both countries are similarly faced with the heavy brunt of illegal drug problem.

In Indonesia, the severity of the drug problem is reflected in the statistics compiled by the agency which revealed that 4.5 million of Indonesians are drug addicts and there are about 40-50 people who die every day because of narcotics ( $\mathrm{Ng}$, Kissenkoetter, \& Sorby-Adams, 2015). Even more alarming to know that a huge of chunk of this population of these drug users are still part of the youth sector. In the case of the Philippines, a 3 million 'guesstimate' of drug users is being asserted by the current administration. This figure is far higher from the 1.8 million drug users estimated by the 2015 survey of the Dangerous Drug Board under the previous administration of Former President Benigno Simeon Aquino. The large number reinforces the reported claims that Asia is known as a major platform for drug production and trafficking (Tanguay et al., 2015).

In response to the alarming drug problem, President Rodrigo Duterte of the Philippines launched the Philippine War on Drugs immediately after he was inaugurated as the 16th president of the Republic. The Philippine Drug War distinctly involves to barrels, hence why it is also called the Project Double Barrel. The project double barrel refers to two strategies employed in countering the drug problem. The upper barrel is described to target those who are in higher offices such as the politicians, military officers, judges, and those who occupy public office. The lower barrel targets street-personalities and is known to be the Project Tokhang which is made up of two terms 'toktok' (meaning knock) and 'hangyo' (meaning plead). 
Indonesia, on the other hand, mainly has death penalty as its strongest feature that identifies the Drug War launched by President Joko Widodo. President Joko Widodo declared that Indonesia is on a state of emergency for drugs and have called for stricter law enforcement. Almost immediately after President Joko Widodo assumed the presidential seat, he announced the return of executions to those who are convicted and are in the death row. This initially created a deterrent to drug trade. The refusal to grant clemency also created tension-filled relations with other countries, as foreigners in the death were refused to be granted clemency and be spared from executions by President Joko Widodo. President Joko Widodo also showed admiration and encouragement to the Philippine Drug War.

During the state visit of President Duterte to Indonesia, both president acknowledge the severity of the drug problem that both countries face. Both presidents also stated that both Indonesia and Philippines will develop good relations and cooperation in countering the drug problem. Domestically, public support towards the Drug War in both the Philippines and Indonesia have been widespread since its commencement. It is, however, worth noting that despite its popularity within the domestic bound of both Indonesia and Philippines, both campaigns have received separate and individual criticisms and condemnations from the international community. These criticisms are founded from the alleged extrajudicial killings practiced by the Philippine Law enforcers, and Indonesia's bold executions of drug offenders in the death row and the president's orders to shoot drug offenders during encounters. Intensively delving into the drug situation in both Indonesia and the Philippines, the contextualized discussions are presented in the succeeding parts of the paper. Lasco (2018) noted that the drug policy in the Philippines is being evaluated 'with little or no input on how drugs and the drug war are actually lived. While Stoisescu (2017) described the Indonesian Drug War to be a plain political ploy of President Joko Widodo to earn back the support of the public. To give a clear picture of what the drug war in Indonesia and Philippine is, this article has come to birth.

As both countries, Indonesia and Philippines, rise above international condemnations and criticisms, it is interesting to see the following features of the drug war of Indonesia and Philippines: (1) The severity of the drug problem, (2) The role played by the Political Figure as the face of the campaign, (3) The strategies used, and (4) The criticisms. The study contributes greatly in analyzing the current state of drug policy in Southeast Asia. This also explores relations and cooperative efforts established in continuing war against drugs fought be countries, societies, communities, and in the core, even families.

\section{The Context: Severity of the Problem}

Indonesia and Philippines, both situated in the region where the infamous golden triangle is at, and where drug use is at its highest (Asian Region), face a serious challenge in public health, peace and order, and community development. Understanding how severe the problem of Drugs in both Indonesia and Philippines would entail an understanding of the respective domestic situations. An elucidation of where the country is situated in, the important events that are related to worsening of the drug issue, and how the society views the issue, are discussed extensively in this literature. 
First is the case of Philippines. The Philippine is an archipelagic state located in Southeast Asia. (Demographic). With the lengthy coastlines and border, the country's geographic feature poses a challenge for security, police motoring, and customs control. Mirasol (2017) revealed that the country is being used as a hideout for international drug syndicates, money laundering haven, and recreation place. The Philippines was revealed to be a major transshipment point and destination country for methamphetamine or locally known as "shabu" (Mirasol, 2017).

The Philippines has just recently upped its efforts in countering drugs after Rodrigo, the longtime Mayor of Davao, was elected as President. A considerable large number of people are involved in both the use and sale of illicit drugs. In the year 2015, the Dangerous Drug Board reported a 1.8 million estimate of drug users in the Philippines. This is, however disputed by President Duterte when he was elected President in the year 2016. President Duterte argued that an estimation of 4 million drug users is the current numbers that determine the severity of the Philippine drug problem. A report by Dennis Carcamo of PhilStar, 19 February of 2015, reflected the facts from Philippine Drug Enforcement Agency showing that ninety-two percent $(92 \%)$ of the barangays in the Philippines were penetrated by the menace of illegal drugs. Duterte also revealed the Chinese drug trafficking organizations known as Triads in collusion with Mexico's drug cartel, Sinoloa, that are mainly in control of the narcotics market in the Philippines (Mirasol, 2017). The 2016 report from the Dangerous Drug Board reveal that a mean age of 31 years old were admitted for drug rehabilitation and an age range of as young as 9 years old to as old as 66 years old. Alarmingly, the mean age that the admitted drug users reveal to have first tried illegal drugs is at the age group 15 to 19 years old.

Moving into the case of Indonesia, it is important to provide a short background of Indonesia that may provide added understanding of the context. Indonesia was colonized by the Dutch and after Indonesia declared its independence from the Dutch in 1945, it was only after in 1949 that the Dutch recognized the independence of Indonesia and officially withdrew from the Indonesian archipelago (DFAT, 2017). It is the largest archipelagic state in the world with more than 17,500 islands and a 258.3 million total population estimate (DFAT, 2017).

The United Nation Office on Drugs and Crime (UNODC, 2016) reported that Indonesia has one of the highest numbers of drug users in the world. An estimate of 2.9-3.6 million users are recorded in Indonesia, which at an average is $1.5 \%$ of the total population of the country of Indonesia. Alarmingly, 22\% of the $1.5 \%$ of drug users are teenagers (Linchia et al., 2017). In the 2014 Survey of the National Narcotics Agency (BNN), it was revealed that there are 4.1 million users (Cook, 2018). The $2016 \mathrm{BNN}$ report also revealed an estimated 40-50 deaths per day caused on illegal drugs and costing 72 Trillion Indonesian Rupiah every year. The alarming rate of Drug abuse in Indonesia has pressured the government to respond with more aggressiveness and intensity. Linchia et al., (2017) argued that addressing the drug problem is vital as it 'disturbs the national stability' (Linchia et al., 2017, p. 158). Also, the 2016 BNN report revealed that drug abuse and trafficking is most prevalent among students in the following province: Jakarta, Yogyakarta, North Kalimtan, East Kalimantan, North Sulawesi, West Java, South Sumatera, West Sumatera, East Java, and South Sulawesi 
(Hapsari, 2017). The intensified effort on the part of the Indonesian Government resulted to an increase of prison population and overcrowding of the correctional facilities. In a span of two months, from January to March of 2017, a recorded increase of 12,000 raised concerns over the overcrowding situations in the prison facilities (Ramadhani, 2017). Yassonna Laoly, the Minister of Law and Human Rights was reported stating that a cell that was designed to accommodate five inmates is forced to accommodate 40 prisoners; an apparent overcrowding problem (Ramadhani, 2017).

In a similar state, the drug problem of Philippines and Indonesia trickles down into the younger generation which further accentuates the threat of the quality of future of any society. The study of Yi et al. (2017) conducted in the countries of Cambodia, Indonesia, Laos, Malaysia, Myanmar, the Philippines, Singapore, Thailand and Vietnam, the results revealed that in the countries of Philippines, Indonesia and Laos, a high prevalence of illicit drug use among university students was recorded. Briola (2017) also supported stating that the adverse effects of drug use affect the youth greatly. This is confirmed by the Drug Report of UNODC (2016) stating that most surveys reveal that there is reportedly higher drug use prevalence among young people than among adults and the gender divide is also narrower among young people than among adults (UNODC, 2106).

In the month of September, 2016 President Duterte travelled to Indonesia for a visit and both political figures have expressed their determination to counter the problem with intensity. The two presidents have sat together and discussed how they can aid each other's effort, policy, and strategy to effectively address the problem. In the joint statement, President Duterte clearly stated:

\section{"We share the deep concern over trade in illict and illegal drugs and its impact on our society. We will seek ways to intensify cooperation and the campaign against this menace. We will do our part in contributing to the aim of a drug-free ASEAN community."}

In this visit, when asked about the magnitude of the country's problem, President Joko Widodo answered President Duterte that he has 4 million drug addicts in his country while President Duterte then recalled to have answered Indonesia's president that Indonesia only have a few thousand more than Philippines. Addressing the drug problem, both presidents enforced a domestic policy of their own in their respective countries. Robust laws and stronger enforcement strategies are the current efforts. The two figures have bother become the faces of their respective drug wars. This is due to the fact that both their administrations have made the drug war its pillar policies.

\section{The Faces of the Campaign: Indonesia and Philippines}

The War on Drugs in Philippines is the core policy of the administration of President Duterte (Mazo, 2017). It is described to be the cornerstone policy that would describe the rise and fall of Duterte. Some scholars even described it to be the key policy of Duterte administration's policy outlook (Tigno, 2017) that would define the success and failure of the entire 6-year term of Duterte (Bautista, 2017). Despite the criticisms from the international community of 


\section{$\triangle$ Macrothink}

Duterte's Drug War, Duterte remains firm on his relentless campaign to eliminate drugs. This campaign included publicizing a narco-list obtaining politicians, retired judges, military officers and other personalities that were allegedly linked to drug trade (Chapman \& Babor, 2017).

President Duterte, is a long time mayor of Davao City, a highly-urbanized city in Mindanao, that was ranked to be among the safest cities in the world in the year 2015 (Hegina, 2015). Tigno (2017) argued that a Duterte is widely supported by not only the Filipinos in the Philippines but also abroad, as evidenced by the widest electoral support that Duterte won over from the overseas absentee voters. Furthermore, the main argued factor despite Duterte's win is his strong-personality and unconventionality, which brought a refreshing change to the campaign period and have reinforced the frustration of many of the people to honey-talking politicians with unfulfilled promises (Tigno, 2017). Bautista (2017) described Duterte to be a populist president who is unfazed by the condemnations thrown by the international community. He was labeled many things by the international media. Some labelled him the Trump of Asia. Another controversial label was the label given to him by a French Press was 'The Punisher'. These have stirred some mixed perceptions on what type of a president he is (Teehankee, 2017) and on whether the Philippine society has lost its moral compass (Bautista, 2017).

President Duterte enjoys very high satisfaction ratings from his constituency, evidenced by an approval rating of 83 percent from a 2017 Pulse Asia Survey. Wide support base of President Duterte, however, does not give him any assurances of the future of his presidency. Tigno (2017) argued that the President must not only rally people to support him but he must strengthen the institutions outside of his influence. A poll revealed that 7 to 8 out of Filipinos support Duterte's drug war (Coca, 2018). In a survey conducted for this study, involving 173 university students of the Philippines, revealed that majority of young Filipinos are supportive of Duterte's Drug War. Figure 1 below presents that almost always, 72.3 percent of young Filipinos are willing to support the War on Drugs of Duterte.

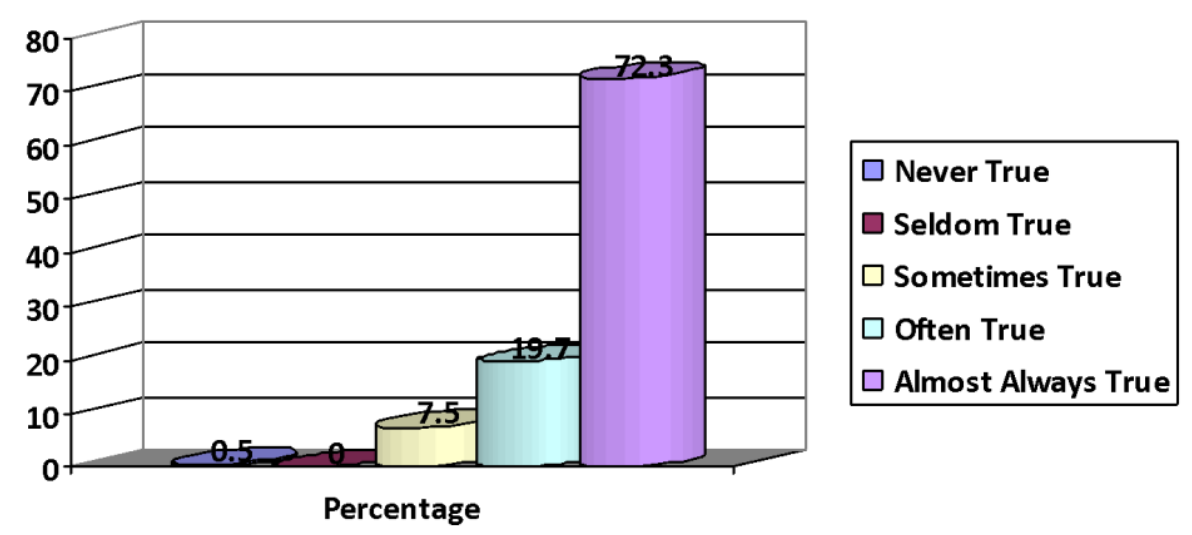

Figure 1. Support to Duterte's Drug War

The play of populism has been seen to be the main backbone of the hardline approach on 
drugs that the ASEAN region in general, more than just Indonesia and Philippines appear to forward. This populist rhetoric is comprised of tough laws, painted to be enforced in the name of security and in defense of the national sovereignty (Coca, 2018). In the case of Philippines, the populist rhetoric has proven to have worked very well. During the 2016 Presidential Campaign, Duterte has loudly campaigned for tougher approaches against drugs and it did not come as a surprise that Duterte was elected, as he won with a huge lead from the other presidential candidates. In the case of Indonesia, Joko Widodo has long advocated for tougher laws (Cook, 2018) and it was no longer a shock for the country when the return of executions happened. Interestingly, when rounds of executions happen an increase of support for Widodo and a surge of approval over his performance are recorded. Same strategy was employed by the ruling party who launched the drug crackdown, and during the elections won $70 \%$ of the seats (Coca, 2018). Similarly, Lao Prime Minister Thongloun Sisoulith won support after he declared an anti-drug and corruption campaign (Coca, 2018).

In the case of Indonesia, the face of the Drug War is President Joko Widodo. President Joko Widodo was elected in the 2014 National Elections with a winning margin of $6 \%$ (BBC, 2014). In a BBC feature of President Joko Widodo, he was described to be a 'clean politician in touch with the masses'. He was a two-time mayor of the city of Solo and a former governor of Jakarta. He was described to be 'the vessel for progressive Indonesian hopes of building a prosperous and tolerant country' (Emont, 2016). Joko Widodo has stated that drugs is the scourge in Indonesia (Emont, 2016) which consequently resulted to the tougher enforcement of drug policies. In defense of the tough drug laws under his administration, a CNN interview undertaken by President Joko Widodo in culmination of his first 100 days in power, Joko Widodo indicated that every day 50 people die in Indonesia because of narcotics, which totals to 18,000 deaths per year. This however contested (BNN, 2015). Joko Widodo boldly stated, "The decision of death penalty is on the court. But they can ask for amnesty to the President. But I tell you there will be no amnesty for drug dealers." Joko Widodo has even gained the reputation as Indonesia's executioner-in-chief (Pilling and Bland, 2015).

The Amnesty Director for Southeast Asia and Pacific, Rafendi Djamin that Joko Widodo could become "the most prolific executioner in the recent Indonesian history (Taylor, 2016). Jonathan Pincus, president of the Rajawali Foundation, a think-tank, commented that Joko Widodo 'is trying to look like a strong leader' believing that it is appealing to his support base (Pilling and Bland, 2015). This is supported by various commentaries (Stoicescu, 2017) arguing that Widodo's punitive measures are seen to be strategic ploys to revive his popularity and redeem his credibility which has suffered greatly on his first months in office. Simandjuntak (2015) reinforced that the popularity of Joko Widodo waned six months after he was elected as evidenced by its decrease to only around 44\%. Even before the election, there were emerging critics during the campaign period that Joko Widodo was not 'tough enough' (Sulaiman, 2014) compared to his then and now opponent for presidency, Prabowo Subianto. Hence why despite international pressure, the $86.3 \%$ of Indonesians, who strongly support the executions of drug offenders, becomes a strong domestic pressure to Joko Widodo. His tough stance is also interpreted as his way of casting himself as a strongman instead of the 'puppet of the elite' he was criticized to be (Stoicescu, 2017). Furthermore, the 


\section{Macrothink}

Journal of Public Administration and Governance

ISSN 2161-7104

2019, Vol. 9, No. 1

capital punishment as a main deterrent strategy used by the government of Indonesia against drug, play a political function as it boosts the government's popularity, and refocus the attention away from unaddressed corruption (Simandjuntak, 2015). Coco (2017) argued that one reason why the War on Drugs in Indonesia is considered to be more political than factual is the apparent rise of Joko Widodo's approval ratings, 'every time there was a round of executions'.

Despite being pressured internationally to rethink its drug policy, President Joko Widodo remained firm with his tough stance and has garnered widely support, as a result. In a report published by the National Narcotics Agency of Indonesia (2016) and reflected in Figure 2 below, almost $93 \%$ of the respondents from the survey conducted declare to be supportive of heavier penalty on drug abuse while $90 \%$ agree that drug is the biggest crime in Indonesia (BNN 2016).

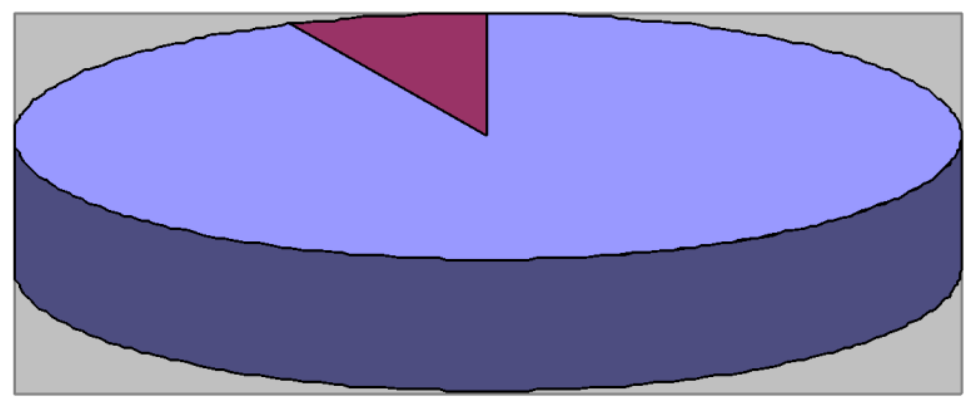

Figure 2. Support to heavier penalties for drug Crimes, BNN (2016)

\section{The Strategies}

The Philippine case recorded an increased and intensified effort in countering drugs. The year 2016 is an important time factor as it is the commencement year of the War on Drugs driven by President Rodrigo Duterte's marching order to eradicate illicit drugs in the Philippines. An astounding 1, 176, 523 pushers and users surrendered to authorities after the launch of Duterte's Drug War (Mazo, 2017). Governments were tripled in effort of eradicating drugs. A total of 54, 340 drug operations were conducted in the year 2016, and as resultant of this increased drug operations 53,674 drug personalities were arrested (Dangerous Drug Board, 2016).

In Figure 3 below, a record of 54,340 operations were conducted in the year 2016 which reflects a 271 percent increase from the drug operations conducted in the year 2015. This verifies an intensified effort of the Philippine government in implementing the War on Drugs. 


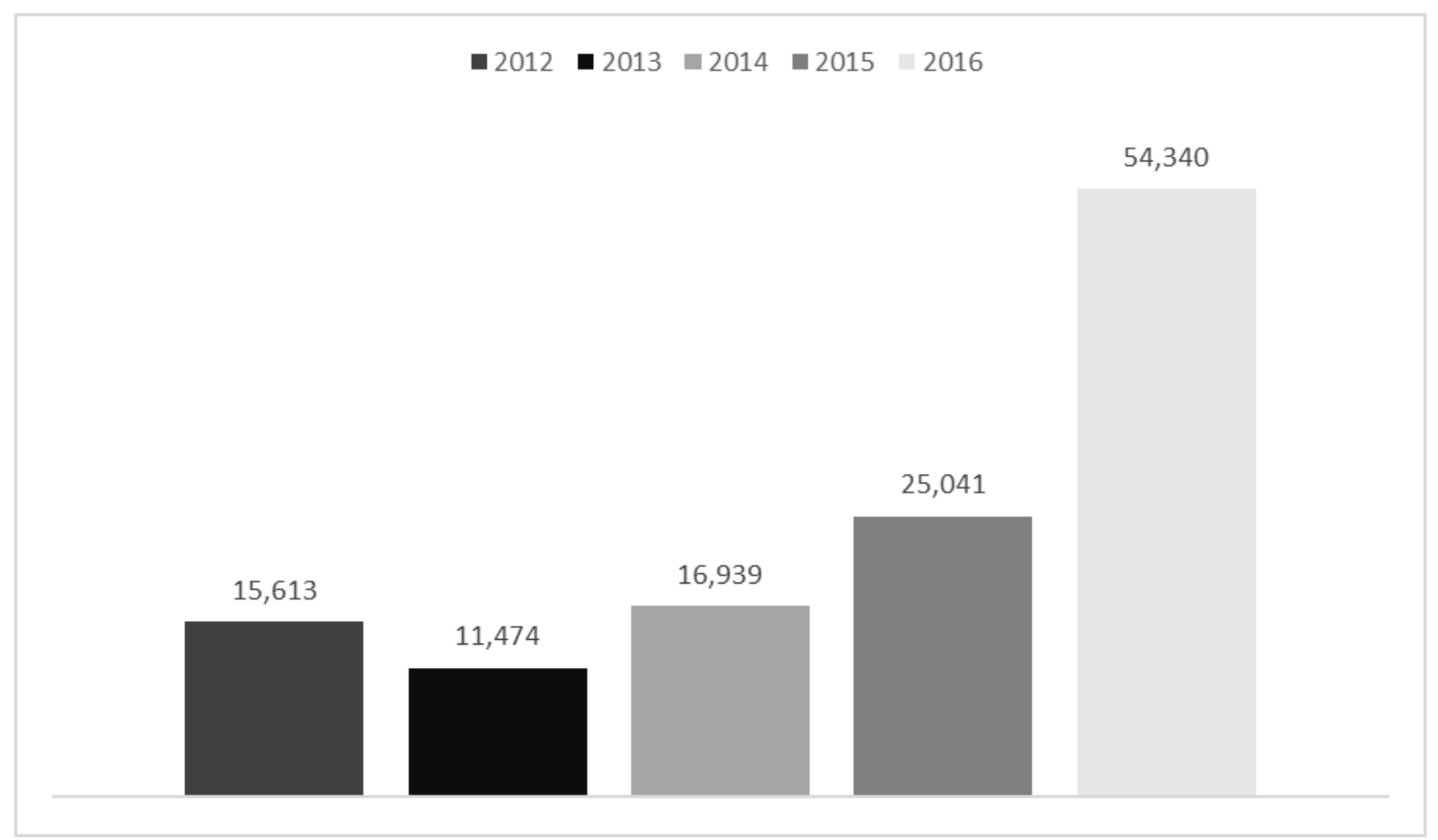

Figure 3. Anti-Drug Operations Conducted from 2012-2016. Source: 2016 Annual Report,

Dangerous Drug Board (2016)

Specifically, the drug campaign is under the helm of the Philippine Drug Enforcement Agency, in coordination and with the support of the Philippine National Police Drug Enforcement Group (PNP, 2017). Under the leadership of Director General Isidro S. Lapeña, PDEA aimed at bringing the anti-drug campaign down to the grassroots level (PDEA, 2017). The campaign involves both high-impact operations and targeting of high-value targets. The Project Tokhang of the Philippine National Police on the other hand, primarily focuses on street-level drug personalities.

Reportedly, the conduct of high-impact operations and the arrest of high-value targets has created a disruption on the supply chain of illegal drugs (PDEA, 2017). High-impact operations involve (1) dismantling of clandestine laboratories and chemical warehouses, (2) dismantling of drug dens and tiangge (Small stores), (3) seizures of high-volume of drugs (PDEA, 2017). From the 1st of July, 2016 to the 1st of January 2018, there are a number of considerably huge accomplishments recorded that the Philippine Drug Enforcement Agency and the Philippine National Police have reported. 183 dens and clandestine laboratories were dismantled (PNP, 2018) and a 19.34 Billion pesos' worth of drugs, laboratory equipment, controlled precursors and essential chemicals (CPECs) were seized. Geopolitically, 3385 barangays were drug-cleared (PDEA, 2017).

High Value Targets, on the other hand, refer to the drug personalities, leaders and members of drug groups, and other drug-involved personalities with government connections and political positions, including celebrities, members of international drug syndicates, members of armed groups and other famous personalities (PDEA, 2017). Combined efforts to clear the streets from illlict drugs, the PDEA and the PNP increased its efforts. PNP (2018) reported that from from the 1 st of July, 2016 to the 1st of January 2018, there are 81, 919 Anti-Drug operations 
conducted, 119,361 drug personalities arrested, 3,987 drug personalities who died in the operations. Furthermore, 446 government workers were arrested in which 213 are government employees, 189 are elected officials, and 44 are uniformed personnel (PNP, 2018).

Also, several policies were put in place in the effort of improving the strategic implementation of the Drug policies. The first one is the Dangerous Drug Board Regulation No. 1, series of 2016 which provides incentives to law enforcers with exceptional accomplishments related to the anti-drug campaign. The second is the Dangerous Drug Board Regulation No. 2, series of 2016 which provides a reclassification of drug-affected barangays for clearer monitoring, policy formulation, and response from respective local government units. Another is the Dangerous Drug Board Regulation No. 3, series of 2016 which mandates the coordination of local government units to national government agencies and non-governmental organizations, to provide livelihood programs and trainings for 'surrenderers' to aid their reintegration to the community as productive drug-free citizens (DDB, 2016).

The Philippine Drug campaign also include efforts of collaborating with other countries, regional, and international bodies. Consequently, the Philippines hosted the 5-day drug prevention training and workshop for ASEAN member states held at Dusit Thani Hotel, Makati City, Philippines from the 25th to the 29th of June, 2018 (DDB, 2018). The ASEAN Training was primarily centered on the Universal Prevention Curriculum (UPC) published by the United Nations Office on Drugs and Crimes (UNODC) in 2012 (DDB, 2018).

Other alternative programs aimed at providing rehabilitation were described to be 'superficial' and unsupported by evidence-based interventions (Mazo, 2017). Among these Anti-drug efforts organized locally were Zumba, Alternative Learning Education, and Livelihood programs. The Valenzuela City, for example has provided community-based and center-based rehabilitation, and reintegration programs, food subsidies, and livelihood support that was described to facilitate transformation (Mazo, 2017). Another case is in Tacloban City, Leyte where the Voluntary Transformational Rehabilitation Plan Community-Based Approach and Moral Recovery Program was introduced - a joint effort of the Local Government Unit (LGU), the Religious groups, the Department of Interior and Local Government (DILG), Philippine Drug Enforcement Agency (PDEA), the Philippine National Police (PNP). And the Department of Social Welfare and Development (DSWD). The Rehabilitation and Recovery Program of Tacloban was designed with a three-phase modular approach: Self-Knowledge and Personality Development, Family Healing and Reconciliation, and Community Integration (Mazo, 2017). Hechanova (2018), the head of the Psychological Association of the Philippines (PAP) Task Force on Drug Recovery, argued that around $90 \%$ of the reported drug users are considered to be "low-or-mild-risk" users that are not in need of rehabilitation (Mazo, 2017). Hechanova (2018) further argued that most of the drug users succumbed to drugs due to pressure of temptations, work, and environment. The Philippine Association of the Philippines revealed that $90 \%$ of the drug users have dwellings in communities of violence while $60 \%$ suffered from emotional neglect or abuse growing up (Mazo, 2017, p. 185). 


\section{Macrothink Institute ${ }^{\mathrm{TM}}$}

The Indonesia Drug war on the other hand, employs the Penyalahgunaan Peredaran Gelap Narkoba or known as the P4GN, which translates to Prevention and Eradication of Drug Abuse and Illicit Trafficking. The drug laws of Indonesia are one of the toughest drug laws in the world (Llewellyn, 2018) and one of the main feature of the Indonesian Drug War is the return of the executions of convicts in death penalty. Only two months, after Joko Widodo sworn into presidency, he declared a state of emergency on drugs and gave marching orders for the execution of $14 \mathrm{drug}$ offenders in the death row (Stoicescu, 2017). The use of death penalty in Indonesia is legalized in a wide range of offences, to name some; terrorism and drug-related offences and there are at least 215 people currently under sentence of death (DFAT, 2017, p. 33). Executions are done through death by firing squad. Survey reveals that $84.6 \%$ of the Indonesians support the death penalty for drug offences, $60.8 \%$ reporting that drugs destroy the young generation and $23.7 \%$ believing that death penalty has a deterrent effect on drug crimes (Simandjuntak, 2015, p. 2). Also, on a weekly basis, law enforcement agencies gather the media and parade the drug users, dealers, and the narcotics that were confiscated (Ambrose and Gooch, 2016). Coco (2017) reported that President Joko Widodo, gave marching orders to the police and the Badan Narkotika Nasional (National Narcotics Bureau, BNN) to not hesitate in shooting drug offenders because they are "ruining our country". This was a recorded shift of approach to drug offenses.

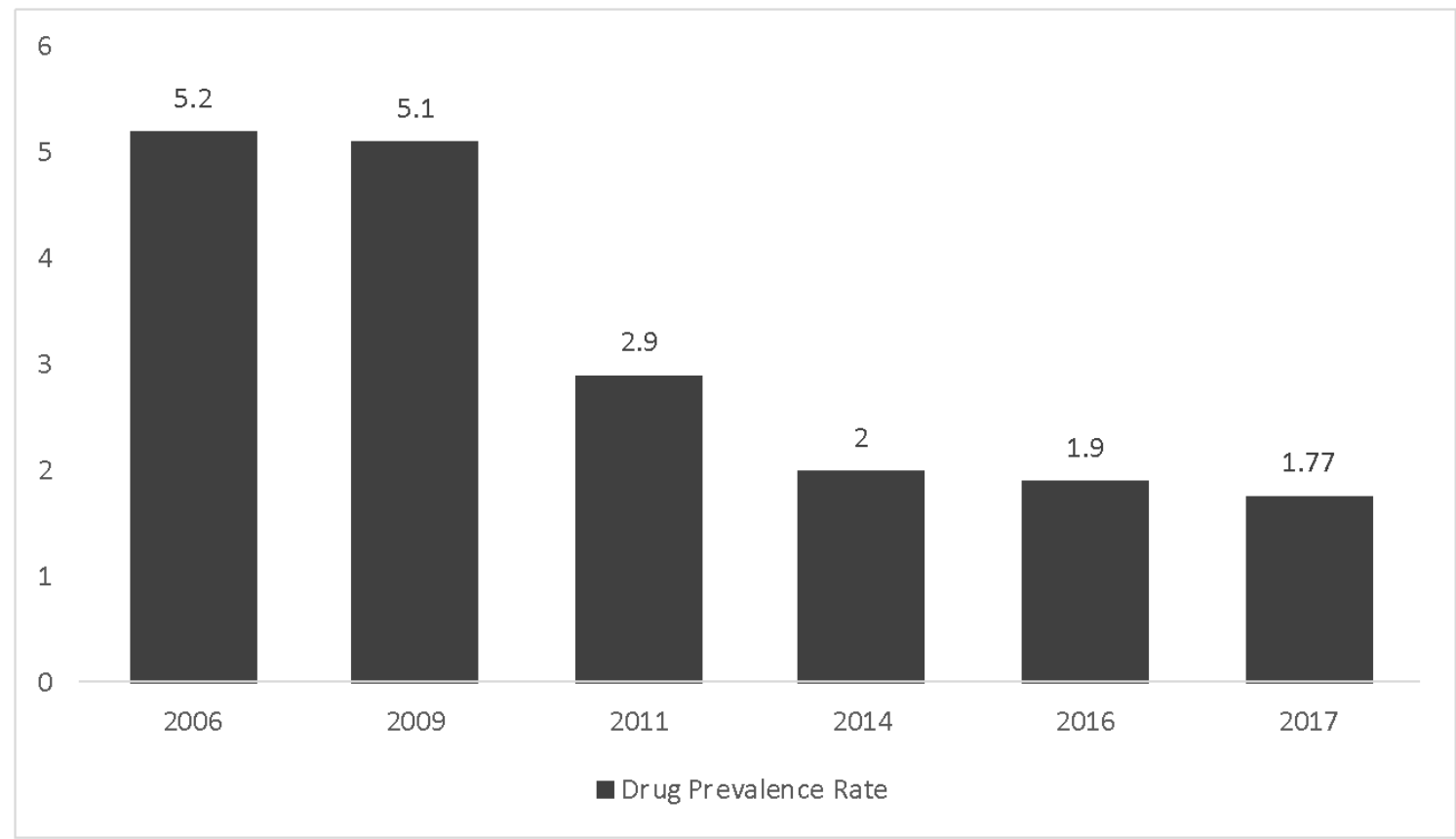

Figure 4. Indonesia’s Drug Prevalence: 2016 BNN Report. Source: National Narcotics Agency (BNN), 2016

In a report from the National Narcotics Agency (BNN), the drug prevalence trends from 2006 and 2016 have decreased as illustrated in Figure 4. This is supplemented by an even decreased rate in the year 2017. The joint research conducted by BNN and the University of Indonesia revealed a prevalence rate of 1.77 percent for 2017 which means 3.3 million of Indonesians are drug abusers (Tempo.Co, 2018). Consequent to the intensified drug campaign, 
423 cases were uncovered by the BNN from January to June 2017 (Hapsari, 2017). In the same time frame, 597 arrests were recorded and 5 arrested drug personalities were foreigners (Hapsari, 2017).

In addition, another effort is the Compulsory reporting of Drug Abusers. The challenge however is the reported negative perception and reluctance of reporting a family member for drug use due to the fear of inviting disgrace to the family (BNN, 2016). This mean that there is still a low social understanding of the Compulsory reporting. Also prevalent is the compulsory treatment centers. Tanguay et al. (2015) argues that compulsory centers that is a common practice in Cambodia, Lao PDR, China, Myanmar, Malaysia, Thailand, Vietnam, Philippines and Indonesia but it is criticized to have generated no positive health outcomes. Compulsory detention has revealed to have resulted into higher relapse rates and higher HIV-transmission risks (Tanguay et al., 2015). Tanguay et al., recommends voluntary community-based centers that is integrated with the national system for responsibility-sharing among agencies concerned. This should be followed by a transition from national treatment centers to community-based treatment centers as it would be, argued Tanguay et al. (2015), economic, medical, and sustainable community development.

The thrust for rehabilitation is in the present priority of Indonesia's Narcotic Agency. The instatement of a new chief for the National Narcotics Agency (BNN), Heru Winarko, puts a different direction to Indonesia's anti-drug campaign. He was put in office after the retirement of Budi Waseso. In an interview with Tempo.Co News, Mr. Winarko said that the orders given to him by President Widodo were to reduce the trafficking of narcotics, to reduce the number of new users and the incidence of relapse of recovered drug users.

Tough approaches against drugs does not come as a sudden policy shift in the southeast Asia. Southeast Asia has a long history of tough drug laws (Coca, 2018). Singapore has a zero-tolerance approach to drugs (Coca, 2018). While a number of southeast Asian countries Indonesia, Malaysia, Thailand, and etc.) retain death penalty for drug crimes (Coca, 2018). Interestingly, statements of encouragement and admiration towards Duterte's drug crackdown approach also arose, not only in Indonesia but also in neighboring countries. Coco (2018) noted how the Prime Minister of Cambodia, Hun Sen requested for Duterte's help to crackdown the narcotics problem in Cambodia and this effort has led to 8000 arrest in the year 2017. However, Strang (2012) argues that the reasoning behind the drug polices might less evidenced-based, non-scientific in nature and are more centered on what the public and policy-makers value. This forwards that drug policies are more value-driven and politicized than scientific and evidence based (Strang, 2012).

\section{Criticisms}

Criticisms and condemnations have rained on both Indonesian and Philippine Drug Wars. Coca (2018) described the Philippine Drug War to be the 'most conspicuous and controversial'. Baustista (2017) argue that the president, a lawyer and long time public servant, knows what is enshrined in the Philippine Constitution and under the international law, but regardless, still excuses the persistence of the dangerous and bloody Drug War by reasons of necessity. Briola (2017) has strongly refuted that the bloody drug war has only 
went down into 'more violence, larger prison population, and the erosion of governance' (Briola, 2017, p. 82). Hence why Briola (2017) firmly advocated for an approach that is strongly anchored on proven and evidence-based interventions. Chapman and Babor (2017) links the silence of the scientific communities firstly due to financial insecurity. Bautista (2017) reinforced how the Drug War in the Philippines has transformed into a war against the class that was labelled to be menaces and are not even considered to be humans. It was laid down by Walden Bello (cited in Thompson, 2016) that the current 'War on Drugs' in the Philippines is "war against poor" that "only addresses the symptoms rather than the roots". This is made in support to the statement of Thompson (2016) that the targets of the killings are those who are poor drug users and also "innocent" by-standers and unintended damages who were killed during crossfires. The silence and passivity of the Filipinos is also highly disputed by some scholars, noting that the silence and passivity is a way of active complicity to the erosion of the moral and democratic ideals, and the waiver of constitutional liberties (Baustista, 2017). Briola (2017) emphasized that the Drug problem is a public health problem that is rooted from poverty and the use of criminal justice system only keeps the arrested drug offenders away from treatment and straight into prisons. Lasco (2018) described the Philippine Drug War to an increasing draconian drug policy. It is indiscriminate with no regard to the distinction between drug dependents and occasional drug users (Lasco, 2018). Curato (2017) stressed out that the approach of injecting fear by the government of the Philippines is with hopes that the fear would create a deterrent to drug use. Lasco (2018) argued that the young drug users use various tactics to avoid law enforcers and that the young drug users feel alienated form the government and from the society due to the mistrust that they have towards the police officers and the society.

In the case of Indonesia, criticisms on the approach arose. Mainly on the executions and the refusal to grant clemency but also because of the 'climate of fear' that the war on drugs has created (Ambrose and Gooch, 2016). Ambrose and Gooch (2016) also reported a revelation of Sugiharto, an outreach worker of the Indonesian Drug Users Network, that the number of HIV infections has risen because people has began sharing needles. Main arguments thrown against the drug war is how it unfairly punishes addicts (Ambrose and Gooch, 2016). One main criticism on Indonesia's Drug however is the rapid increase of the prison population. From January to March of 2017, an increase of 12000 prisoners was recorded (Ramdhani, 2017). The drug war has certainly contributed to the prison overpopulation issue. 70 percent of Indonesia's total prison population is made up of low-level drug offenders (Llewellyn, 2018). In the case of Indonesia, criticisms to the 'War on Drugs' strategies find its roots from the very low rehabilitation services provided to the persons caught with small quantities of drugs. According to a report from Aljazeera (2016), there have been budget cuts imposed to the drug rehabilitation funds. In a statement of the Social Affairs Minister Khofifah Indar Parawansa, he said:

"Many of those who are in prison should not be sentenced to prison at all, they should be sent to rehab."

In a report that was released by the United Nations, and cited in the report of Aljazeera, it was revealed that less than 1 percent of dependent users got treatment in 2014, compared with a 
global average of 16 percent. The budget cut of the rehabilitation services is widely questioned as the AlJazeera report (2016) revealed that while there is a reduction in the rehabilitation funding, the president however has tripled the budget allocated to the national counter-narcotics agency known as BNN.

A criticism to the "War on Drugs" of President Widodo from Andreas Harsono of Human Rights Watch in Jakarta has also been laid down stating that,

"They want to build more prisons but they should be building more rehab centers and making more treatment options available,"

Gloria Lai, the director of the International Drug Policy Consortium, noted there is no evidence that links the imposition of death penalty over drug offences deter drug crimes (Coca, 2018). Lai further added, as cited by (Coca, 2018), that the high numbers of arrests do not signify a decrease in drug supply nor do it mean that health and safety in communities have improved. Strategies devised by the government must be subject to rigorous evaluations. Strang (2012) argues that incarceration of drug dependents only denies them from needed treatment and medication and thus becomes a cause of health concern. Tanguay et al., (2015) also argues that in the southeast Asian region, criminalization of drugs reveal to do more harm than good not only to the individual but to the entire society. Rethinking approaches is called for.

\section{Conclusion and Recommendation}

There are still so much skepticism surround Indonesia's Drug War and Philippine's Drug War. It is, however notable that there is widespread domestic support from Indonesians and Filipinos toward their respective drug campaigns. Several caveats regarding the drug wars have been mentioned. In the case of Philippines, the controversial allegations of Extra Judicial Killings and the bloody approach. In the case of Indonesia, main criticisms emerging are the ballooning population in the prisons, the executions, and the poor rehabilitation services.

On a lighter perspective, it is worth noting that drug operations have truly intensified and the massive support from the domestic public is what fuels the drug campaigns of both governments. There are however several improvements that the government of both Indonesia and Philippines must look into. Firstly, it is the interesting to explore alternative approaches. The lack of political will to engage into alternative approaches in Anti-drugs campaign is a common obstacle in all South East Asian countries (Baldwin, 2013). Incarceration only denies dependents from the treatment they need while compulsory rehabilitation also have high records of relapse. Tanguay et al. (2015) recommends voluntary drug treatment and support services and policies that are shifting from criminalization and punishment of drug dependents. Prior to that, a societal acceptance must be established wherein the stigma of drug users being seen as less than humans, as criminals, and other negative labels must be eradicated. The promotion of a drug-free community must begin with the recognition that drug users are in need of treatment and the community must be supportive in the re-integration process of the reformed citizens. Strang (2012) also argue that this effort must be enforced by environmental intervention wherein the availability of illegal drugs in the streets is dealt with, and the educational system integrates awareness drive, and knowledge dissemination of the adverse 
effects of illegal drug use. Interventions must be implemented with prudence wherein responses must be tailored on the cultural context of respective countries and that allocation of technical and financial support must be prioritized (Tanguay et al., 2015). The move from stricter law enforcement, punitive, and bloody drug policies towards a more community-based treatment approach would result to positive health and social outcomes (Tanguay et al., 2018).

Also, as revealed, the great societal danger lies on the fact that the younger generation are more involved and engaged in illicit drug use. This calls for more preventive mechanisms. Strang (2012) supports this emphasizing the need that focused drug prevention efforts must be intensified in schools, media, communities, and health care establishments. Young people of the society are proved to be important targets of drug abuse. Strang (2012) how crucial the period of youth is and how drug prevention must be centered on this particular stage of human development. The young adult stage of human life is when individuals are exposed to illegal drugs, and initiation of use of drugs. Efforts must be focused on drug prevention or if not then delay initiation of drug use, argued Strang (2012). Linchia et al., (2017) highlighted the importance of the socialization of the law to increase the awareness of the youth about the danger that narcotic abuse pose.

Furthermore, with the surrounding controversies of the drug wars, it is important that enforcement agencies must function with transparency, accountability, and complete regard to human rights. This is why it is important for the police officers to rebuild the trust of society towards them. Bevrer (2012), as cited by Lasco (2018), stated that the role of law enforcement must be re-envisioned into one that is supportive of harm reduction, treatment, and protection of human rights.

An understanding of the drug wars and how it may differ from the other drugs wars becomes vital. It is difficult to determine as to whether the drug war has effectively reduced the supply and demand for Illicit drugs as numbers are inconsistent and 'manipulated' (Coca, 2018). But the, 82 percent of the Filipino people who feel safer because of the effects of the War on Drugs (Pulse Asia, March 2017). This must account for something. The question of whether the Drug War of Philippines and of Indonesia would just projectile downwards like the case of Thailand's War on Drugs during the time of Prime Minister Thaksin, remains unanswered. Only time will tell and with President Duterte with more than 3 more years in power and President Joko Widodo with a possible re-election, these Drug Wars are not near from over.

\section{Acknowledgement}

The researchers would like to extend their gratitude to Universitas Muhammadiyah Yogyakarta- Indonesia and to the Jusuf Kalla School of Government.

\section{References}

Ambrose, D., \& Gooch, L. (2016, February 28). Indonesia weighs controversial new drug crime penalties. Aljazeera. Retrieved from https://www.aljazeera.com/indepth/features/2016/02/indonesia-weighs-controversial-drug-cri me-penalties-160228064109348.html 
Aljazeera (2016, August 2). Crackdowns and cutbacks: Indonesia's drug policy. Retrieved from

http://www.aljazeera.com/news/2016/08/crackdowns-cutbacks-indonesia-drug-policy-160802 081040575.html

Aljazeera. (2017, July 22). Joko Widodo: Police should shoot suspected drug dealers. Retrieved from https://www.aljazeera.com/news/2017/07/joko-widodo-police-shoot-suspected-drug-dealers-1 70722104559016.html.

Baldwin, S. (2013). Drug Policy Advocacy in Asia: Challenges, opportunities and prospects. International Drug Policy Consortium Report. ISBN X 0-904932-16-8. www.aidsdatahub.org/sites/default/files/.../drug_policy_advocacy_in_asia_2013.pdf

Bautista, L. (2017). Duterte and his quixotic war on drugs. University of Wollongong Research Online. Retrieved from http://ro.uow.edu.au/lhapapers/2866.

BBC News. (2014, July 22). Joko Widodo wins Indonesia presidential election. Retrieved from https://www.bbc.com/news/world-asia-28415536 accessed on July 23, 2018.

BNN. (2016). Drug Abuse Prevalence Survey in Household in 20 Provinces Budget Year 2015. Center of Research, Data and Information, National Narcotics Board.

Briola, J. (2017). Effective and humane ways to manage the drug problem in the Philippines, a human rights and public health perspective. Torture, 27(1), 82-84. https://doi.org/10.7146/torture.v27i1.26541

Carcamo, D. (2015, February 19). PDEA: 92\% of Metro Manila barangays drug-affected. PhilStar. Retrieved from http://www.philstar.com/nation/2015/02/19/1425462/pdea-92-metro-manila-barangays-drug-a ffected

Chapman, A., \& Babor, T. (2017). Duterte's War on Drugs and the Silence of the Addiction Science Community. Journal of Studies on Alcohol and Drugs, 78(4), 491-493. DOI: https://doi.org/10.15288/jsad.2017.78.491

Coca, N. (2018, January 29). The War on Drugs in Southeast Asia. New Naratif. Retrieved from https://newnaratif.com/journalism/the-war-on-drugs-in-southeast-asia/

Cook, E. (2018, January 12). Beware Indonesia's Quiet Drug War. The Diplomat. Retrieved from https://thediplomat.com/2018/01/beware-indonesias-quiet-drug-war/

Curato, N. (2017). Flirting with authoritarian fantasies? Rodrigo Duterte and the new terms of Philippine populism. Journal of Contemporary Asia, 47(1), 142-153. https://doi.org/10.1080/00472336.2016.1239751

Dangerous Drug Board. (2016). Annual Report 2016. pp. 1-18.

Dangerous Drug Board. (2018, June 26). Philippines hosts drug prevention training for ASEAN member states. Retrieved from 
https://www.ddb.gov.ph/newsroom/360-philippines-hosts-drug-prevention-training-for-aseanmember-states, accessed on July 24, 2018.

Department of Foreign Affairs and Trade. (2017, December 22). DFAT Country Information Report Indonesia. Retrieved from dfat.gov.au/about-us/publications/.../country-information-report-indonesia.pdf

GMA News Online. (2016, August 18). Drug users aren't human, says Duterte. Retrieved from http://www.gmanetwork.com/news/story/579277/news/nation/drug-users-aren-t-human-saysduterte, accessed on July 24, 2018.

Emont, J. (2016, October 20). Visionary or Cautious Reformer? Indonesian President Joko Widodo's Two Years in Office. Retrieved from http://time.com/4416354/indonesia-joko-Joko Widodo-widodo-terrorism-lgbt-economy/, accessed on July 23, 2018.

Hambali, S. (2017, November 21). Why Indonesia's drugs problem is getting worse despite 'shoot on sight' orders and draconian laws. SCMP. Retrieved from http://www.scmp.com/lifestyle/article/2120688/why-indonesias-drugs-problem-getting-worse -despite-shoot-sight-orders-and

Hapsari, P. (2017, July 13). The anti-narcotics agency claimed to have uncovered 423 cases from January to June. Brilio News. Retrieved from https://en.brilio.net/news/40-to-50-people-die-because-of-illegal-drugs-every-day-170713w.h tml, accessed on July 24, 2018.

Hegina, A. (2015, June 24). Davao City improves to 5th in ranking of world's safest cities. Retrieved from http://globalnation.inquirer.net/125132/davao-city-improves-to-5th-in-ranking-of-worlds-safe st-cities\#ixzz5M6192zRd, accessed on 23 July, 2018.

Krever, M. (2015, March 4). After 100 days, Indonesia's President is tested but still goes to the people. CNN. Retrieved from https://edition.cnn.com/2015/01/26/asia/indonesia-president-joko-widodo-interview/, accessed on July 23, 2018

Sabillo, K. (2017, January 6). Duterte approval rating at 83\%-Pulse Asia. Inquirer.Net. Retrieved from http://newsinfo.inquirer.net/859906/duterte-approval-rating-at-83-pulse-asia, accessed July 24, 2018.

Linchia, D., Heningdyah, L., \& Kusumawardhani, N. (2017) Progressive Step of Narcotic Abuse Eradication in Globalization Era. Proceeding the 2017 International Conference on Globalization of Law and Local Wisdom, 1(2), 155-171. ISSN: 978-602-142373-9

Lasco, G. (2018). Kalaban: Young drug users' engagements with law enforcement in the Philippines. International Journal of Drug Policy, 52, 39-44. https://doi.org/10.1016/j.drugpo.2017.11.006

Llewellyn, A. (2018, May 23). Indonesia's Prison System is Broken. The Diplomat. https://thediplomat.com/2018/05/indonesias-prison-system-is-broken/ 
Maulia, E. (2015, March 10). Narcotics Agency: Drugs Kill 33 Indonesians Daily, Not 40-50. JakartaGlobe. Retrieved

from

http://jakartaglobe.id/news/bnn-says-33-die-of-drugs-daily-not-40-50/

Mazo, G. (2017). Transformational Rehabilitation: Community-based Intervention to end the drug menace. International Journal of Research- Granthaalayah. 5(12), 183-190. ISSN: 2350-0530

Mirasol, J. (2017). Cooperation with China on the Philippines' War on Drugs. Center for International Relations and Strategic Studies Commentaries. 4(10):1-3. ISSN: 2423-2920.

Ng, V., Kissenkoetter, M., \& Sorby-Adams, J. (2015). The Death Penalty for Drug Crimes in Asia Report. FIDH \& World Coalition Against Death Penalty. Retrieved from https://www.fidh.org/IMG/pdf/asia_death_penalty_drug_crimes_fidh_wcadp_report_oct_201 5_pdf.pdf

Philippine Drug Enforcement Agency. (2017, June 8). The War on Drugs Goes On: The Impact of Change. http://www.pdea.gov.ph

Philippine National Police. (2017, March 7). PNP Activates Drug Enforcement Group; Double Barrel Reloaded, Tokhang Revisited. Retrieved from http://www.pnp.gov.ph/news-and-information/773-pnp-activates-drug-enforcement-group-do uble-barrel-reloaded-tokhang-revisited, accessed on July 24, 2018.

Philippine National Police. (2018). \#RealNumbersPH Update. Retrieved from http://www. pnp.gov.ph

Pilling, D., \& Bland, B. (2015, May 3). Indonesia: No more Mr nice guy. CNBC. Retrieved from https://www.cnbc.com/2015/05/03/indonesia-no-more-mr-nice-guy.html, accessed on July 23, 2018.

Ramadhani, N. (2017, April 11). Prison population jumped by 12,000 in two months. The Jakarta Post. Retrieved from http://www.thejakartapost.com/news/2018/05/10/prison-overcrowding-serves-in-favor-of-ismilitants.html

Simandjuntak, D. (2015, August 28). Spectacle of the Scaffold? The Politics of Death Penalty in Indonesia. ISEAS Yusof Ishak Institute, 46, 1-8. ISSN: 2335-6677

Strang, J., Babor, T., Caulkins, J., Fischer, B., Foxcroft, D., \& Humphreys, K. (2012). Drug policy and the public good: evidence for effective interventions. Lancet 2012 Vol. 379: 71-83. https://doi.org/10.1016/S0140-6736(11)61674-7

Stoisescu, C. (2017, July 26). Why Joko Widodo's war on drugs is doing more harm than good. Aljazeera. Retrieved from https://www.aljazeera.com/indepth/opinion/2017/07/Joko Widodo-war-drugs-harm-good-170725101917170.html

Sulaiman, Y. (2014, December 17). Why Joko Widodo ordered the execution of drug traffickers in Indonesia. The Conversation. Retrieved from 
https://theconversation.com/why-Joko

Widodo-ordered-the-execution-of-drug-traffickers-in-indonesia-35432

Tanguay, P., Kamarulzaman, A., Aramrattana, A., Wodak, A., Thomson, N., Ali, R., Vumbaca, G., Lai, G., \& Chabungbam, A. (2015). Facilitating a transition from compulsory detention of people who use drugs towards voluntary community-based drug dependence treatment and support services in Asia. Harm Reduction Journal. 12(31), 1-5. DOI: 1186/s12954-015-0071-0

Taylor, S. (2016, July 29). Joko Widodo on path to become 'most prolific executioner in recent Indonesian history' - Amnesty International. Euronews. Retrieved from http://www.euronews.com/2016/07/29/Joko

Widodo-on-path-to-become-most-prolific-executioner-in-recent-indonesian-history, accessed on July 23, 2018.

Teehankee, J. (2016). Duterte's Resurgent Nationalism in the Philippines: A Discursive Institutionalist Analysis. Journal of Current Southeast Asian Affairs, 35(3), 69-89.

Tempo.Co. (2018, March 27). BNN Chief Heru Winarko: I Want to Impoverish Drug. Retrieved from

https://en.tempo.co/read/news/2018/03/27/241917063/BNN-Chief-Heru-Winarko-I-Want-to-I mpoverish-Drug, accessed on July 24, 2018.

Tempo. Co. (2018, April 16). Meth Price More Expensive than Gold, BNN Says. Retrieved from

https://en.tempo.co/read/news/2018/04/16/055917615/Meth-Price-More-Expensive-than-Gol d-BNN-Says, accessed on July 24, 2018.

Tigno, J. (2017). The Philippines in 2017: Popularity Breeds Contempt. Asian Survey, 58(1), 142-148. ISSN: 0004-4687

United Nations Office on Drugs and Crime. (2016). World Drug Report. United Nations publication. eISBN: 978-92-1-057862-2

Yi, S., et al. (2017) Prevalence and associated factors of illicit drug use among university students in the association of southeast Asian nations (ASEAN). Substance Abuse Treatment, Prevention, and Policy, 12(9). https://doi.org/10.1186/s13011-017-0096-3

\section{Copyright Disclaimer}

Copyright for this article is retained by the author(s), with first publication rights granted to the journal.

This is an open-access article distributed under the terms and conditions of the Creative Commons Attribution license (http://creativecommons.org/licenses/by/4.0/). 